\title{
Contribution to the Diagnostic Study of Intestinal Parasitosis, Haiti
}

\section{Daphnee Michel, MPH student}

Quisqueya University, Faculty of Health Sciences (FSSA), Master's Program in Public

Health, Port-au-Prince, Haiti. Quisqueya University, Zoonoses and Food Poisoning Research Laboratory (LAZERIA), Port-au-Prince, Haiti. Haitian Association of Women, Science and Technology (AHFST), Port-au-Prince, Haiti. Center for Planning Techniques and Applied Economics (CTPEA), Port-au-Prince, Haiti

\section{Lucainson Raymond, BS}

Center for Planning Techniques and Applied Economics (CTPEA),

Port-au-Prince, Haiti

\section{Ammcise Apply, MPH student}

Quisqueya University, Faculty of Health Sciences (FSSA), Master's Program in Public Health, Port-au-Prince, Haiti. Quisqueya University, Climate Change Research Team (ERC2), Port-au-Prince, Haiti. Haitian Association of Women, Science and Technology (AHFST), Port-au-Prince, Haiti

\section{Daphenide St Louis, MPH student}

Quisqueya University, Faculty of Health Sciences (FSSA), Master's Program in Public

Health, Port-au-Prince, Haiti. Quisqueya University, Zoonoses and Food Poisoning Research Laboratory (LAZERIA), Port-au-Prince, Haiti. Haitian Association of Women, Science and Technology (AHFST), Port-au-Prince, Haiti

\section{Ketty Balthazard-Accou, PhD}

Quisqueya University, Zoonoses and Food Poisoning Research Laboratory (LAZERIA), Port-au-Prince, Haiti. Haitian Association of Women, Science and Technology (AHFST), Port-au-Prince, Haiti

\section{Max Francois Millien}

Quisqueya University, Zoonoses and Food Poisoning Research Laboratory (LAZERIA), Port-au-Prince, Haiti

\section{Evens Emmanuel, PhD}

Quisqueya University, Climate Change Research Team (ERC2), Port-au-Prince, Haiti

\section{Doi:10.19044/esj.2021.v17n17p64}

Submitted: 15 April 2021

Accepted: 21 May 2021

Published: 31 May 2021
Copyright 2021 Author(s)

Under Creative Commons BY-NC-ND 4.0 OPEN ACCESS

Cite As:

Michel D., Raymond L., Apply A., St Louis D., Balthazard-Accou K., Millien M.F. \& Emmanuel E. (2021). Contribution to the Diagnostic Study of Intestinal Parasitosis, Haiti. European Scientific Journal, ESJ, 17(17), 64. https://doi.org/10.19044/esj.2021.v17n17p64 


\begin{abstract}
Parasitic intestinal diseases are widespread in the world with a higher prevalence in developing countries. They are generally a serious public health problem in tropical countries. In October 2020, a cross-sectional study was undertaken to determine the prevalence of intestinal parasites in patients visiting Fermathe Hospital in Haiti. Data were collected on stool results with the presence of parasites and we used systematic sampling for further information regarding patients with parasitology problems. A summary field survey was also carried out in the surrounding areas with more cases recorded such as Corail, Calbasse, Fort Jacques, Center / Marché Kenscoff, Doco, and Douret for direct observations of the inventory and voluntary interviews with the residents of the area on hygiene practices. The prevalence of intestinal parasites was $31.26 \%$ and the most common species were: Endolimax nana (39.13\%), followed by Blastocystis hominis (14\%), Blastocystis hominis / Giardia intestinales (12.07\%), Entamoeba coli $(5.31 \%)$, and others like Iodamoeba butschlii, Ascaris lumbricoides or combined parasites were less than $5 \%$. The field survey revealed a strong relationship between parasitosis and drinking water, parasitosis, and place of defecation. Although there are health centers in the area, many people use self-medication or empiric therapy. The study highlights the important causes of gastrointestinal disorders that present themselves in this hospital and confirms intestinal parasitosis as a major public health problem in Haiti.
\end{abstract}

Keywords: Intestinal parasitosis, parasitic infestation, neglected tropical diseases, gastrointestinal diseases, Fermathe Hospital

\title{
Introduction
}

Parasitic intestinal diseases are widespread throughout the world but with a higher prevalence in developing countries. They are generally a serious public health problem in tropical countries [Bourée et al, 2015]. Intestinal parasitic diseases are considered as a major cause of morbidity, closely linked to poverty, poor personal hygiene, inappropriate handling of raw foods, lack of sanitation of residues, shortage of drinking water, and fecal contamination of the environment [Juárez et al, 2013]. In addition, intestinal parasitic infections have been found to have significant consequences on nutritional and cognitive status especially among kindergarten and school-aged children because of increased metabolic rate, chronic anaemia, anoxia, and diarrhea associated with heavy worm load [Ezeamama et al., 2005; Okolo et John, 2006; Tamramat et Olowu, 2008, Oluboyo et al., 2014]. The etiological agents of these conditions are diverse and can be classified biologically and morphologically into 3 large groups: protozoa, helminths, and fungi [Pitt and Barer, 2012]. 
Protozoa are unicellular beings endowed with movement [CavalierSmith, 2017]. Depending on the case, they move thanks to plasmopods (rhizopods), flagella, undulating membrane, or cilia [Ringo, 1967]. They appear in asexual or sexual potential, or mobile or encysted, intra or extracellular form [Anderson et al., 1985]. Helminths or worms are identified in adult form of both sexes, in larval, embryonic, or ovular form [Castro, 1996]. The fungi or micromycetes constitute a kingdom in their own right and are microscopic fungi identified in the form of isolated or grouped spores or free or tissue filaments [Cole, 1996]. Among them, the most incriminated classes are rhizopods including: Entamoeba histolytica, flagella, intestinal Giardia, as well as Cryptosporidium spp. Cyclospora cayetanensis, Cytoisospora belli and Microsporidia spp. in immunocompromised patients. [Kiani et al, 2016]. Intestinal parasitoses can be asymptomatic but they often give rise to mainly digestive symptoms (diarrhea), abdominal pain and various lesions [Hechenbleikne et McQuade, 2015]. In some cases, surgery may be necessary to treat serious complications caused by some parasites [Hesse, 2012].

Diseases linked to environmental contamination by microorganisms are numerous in developing countries, especially those caused by bacteria and protozoa transmitted by water [Savioli et al., 2006]. In Haiti, intestinal nematodes are frequent [Champetier de Ribes et al., 2005]. Cryptosporidiosis is responsible for $17 \%$ of acute diarrhea observed in children under 2 years of age and $30 \%$ of chronic diarrhea in patients infected with HIV in Haiti [Pape et al., 1987]. Cryptosporidium parvum has been detected in water samples analyzed in important cities of Haiti [Raccurt et al, 2006; Balthazard-Accou et al., 2009; Brasseur et al., 2011; Damiani et al, 2013; Balthazard-Accou et al., 2020]. Microbial waterborne diseases also are typically spread by fecalcontaminated drinking water or food [Cabral, 2010]. A cross-sectional study was conducted to determine the prevalence of bacteria and intestinal parasites in food handlers working with Cuban health workers in Haiti. Stool samples were taken from 56 food handlers, $26.8 \%$ of whom had bacterial pathogens such as: Blastocystis spp. (9\%), Vibrio cholerae O1 serotype Ogawa, Aeromona spp. and Giardia intestinalis, each with $4 \%$. In addition, the prevalence of intestinal parasites was $19.7 \%$ [Llanes et al, 2016].

Haiti is the most underserved country in the western hemisphere in terms of water and sanitation infrastructure [WHO/UNICEF, 2012]. Protecting the health of the Haitian population through access to safe drinking water and sanitation is a long-standing challenge in Haiti [Gelting et al., 2013]. This work aims to carry out a retrospective epidemiological study over the period from January 2018 to January 2019 at Fermathe Hospital to estimate the frequency of intestinal parasitoses diagnosed in this health institution. and 
to determine the main socio-demographic characteristics of the residents of this zone.

\section{Methodology \\ Brief presentation of the study area}

The commune of Kenscoff is located in the West Department in Haiti, $12 \mathrm{~km}$ from Pétion-ville and $24 \mathrm{~km}$ from Port-au-Prince. It occupies an area of $208.23 \mathrm{~km} 2$ and bounded to the north by Pétion-Ville, to the south by BelleAnse and Marigot, to the west by Carrefour and Jacmel, and the east by Croixdes-Bouquets. Located on the northern slope of the Massif de la Selle, between 600 meters (Morne Calvaire around Pétion-Ville) and at an altitude of more than 2000 meters (Morne la Visite). This commune has five communal sections: Nouvelle Touraine, Sourçailles, Grand Fond, Belle Fontaine, Bongars, and several communal sections.

The present research work is a retrospective cross-sectional epidemiological study that was carried out at Fermathe Hospital from January 2018 to January 2019. Fermathe hospital located at Fermathe 62 (commune of Kenscoff) on the campus of the Mission Baptiste Conservatrice of Haiti $(\mathrm{MBCH})$, has 40 hospital beds and offers all basic services. Its emergency service operates 24 hours a day.

\section{Methods}

In this study, quantitative and secondary data are collected through a questionnaire on the laboratory results of patients from the logbooks of the hospital laboratory. These patients were hospitalized people or others who visited the hospital, and who presented signs and symptoms such as abdominal pain and/or diarrhea, vomiting, fever, anal itching, nocturnal tooth grinding, and malnutrition in children. The Lugol staining technique is used to carry out laboratory examinations.

After collecting the data of stool results showing the presence of parasites, we used interval sampling, with a difference of 5 people between each selected unit which is included in the sample Ke up to the total population. N: 207. A summary field survey was also carried out in neighboring areas with more cases recorded such as Corail, Calabash, Fort Jacques, Center / Marché Kenscoff, Doco, and Douret for direct observations of the state of the premises and voluntary interviews with the inhabitants of the zone on the hygiene practices in progress in the zone.

Qualitative and primary data on the socio-demographic conditions of the population are collected using the information provided at the time of the commemorative collection. Volunteer interviews are conducted at assembly stations in the community with the aid of multi-skilled community health workers in the area (ASCP), assigned to Fermathe Hospital before the 
awareness session on hygiene practices. Through this questionnaire, information on hygiene practices, drinking water, place of defecation, washing of fruits and vegetables before consumption, and others). For direct observation, field visits were carried out and an overview of the houses, the environment, and the children's way of life or behavior (barefoot, even playing on the ground, and others).

\section{Limits}

This study is based solely on secondary data from tests carried out in the Fermathe hospital laboratory.

\section{Data analysis and processing}

All the results of the logbooks of the stool examinations with the presence of parasites were recorded and recorded in an Excel file and analyzed by the R software to determine the most frequent type of parasites. Data from volunteer interviews and direct observations are collected employing a questionnaire applied to each volunteer living in areas with more cases of parasitosis. The Excel program is applied for data recording and the $\mathrm{R}$ software is used for the descriptive analysis of the results with univariate and bivariate analyzes relating to the presence of intestinal parasitosis and hygiene practices.

Interference analysis is used to test the independence of variables to check whether any supposed relationships between said variables are not due to pure stochastic effects. For this, Pearson's chi-square tests were applied and calculated Cramer's V (or even phi) to measure the strength of association of the variables taken in pairs. The problem with the test is to assess the gap between the data effectively and a model of independence. The latter, as its name suggests, certifies that no statistical relationship exists between the variables of interest. And when the difference between the 2 models is statistically significant, we can assume an association between said variables at a given critical threshold.

\section{Results and discussion}

The results relate to the nature, number or frequency of the parasites in the stool

Of the 662 stool examinations performed during the study period at Fermathe Hospital, 207 samples presented one or more intestinal parasites or a percentage of $31.26 \%(207 / 662)$.

The rate of infestation in women (118/207 cases; $57 \%)$ is higher than that of men ( $89 / 207$ cases; $43 \%)$. The average age of patients with the presence of parasites in the stool is 33 years. The results show the presence of parasites isolated or in combination, among which one can count Endolimax nana, 
Entamoeba coli, Entamoeba histolytica, Blastocystis hominis, Giardia intestinalis, Iodamoeba butschlii and Ascaris lumbricoides. The most common intestinal parasite is Endolimax nana (39.1\%) and second is Blastocystis hominis (14\%). (See Tab. 1)

Table 1: : Frequency of parasites identified in stool at Fermathe hospital

\begin{tabular}{lrr}
\hline Name of Parasitosis & Effective & \% \\
\hline Endolimax nana & 81 & 39.1 \\
Blastocystis hominis & 29 & 14 \\
Blastocystis hominis / Giardia intestinalis & 25 & 12.1 \\
Entoamoeba coli & 11 & 5.3 \\
Iodamoeba butschlii & 9 & 4.3 \\
Ascaris lumbricoides & 9 & 4.3 \\
Entamoeba coli / Endolimax nana & 8 & 3.9 \\
Giardia intestinalis & 6 & 2.9 \\
Endolimax nana / Iodamoeba butschlii & 6 & 2.9 \\
Entamoeba histolytica & 4 & 1.9 \\
Endolimax nana/Entamoeba coli / Giardia & 4 & 1.9 \\
intestinalis & & \\
Giardia intestinalis / Endolimax nana & 3 & 1.4 \\
Blastocytis hominis / Entamoeba coli/Endolimax & 3 & 1.4 \\
nana & & \\
Entamoeba coli/ Iodamoeba butschlii & 2 & 1 \\
Ascaris lumbricoides / Endolimax nana & 2 & 1 \\
Iodamoeba butschlii / Entamoeba coli / Endolimax & 2 & \\
nana & & 0.5 \\
Entamoeba histolytica / Endolimax nana & 1 & 0.5 \\
Ascaris lumbricoides / Blastocitis hominis & 1 & $\mathbf{9 9 . 9}$ \\
Ascaris lumbricoides / Giardia intestinalis & 1 & $\mathbf{2 0 7}$ \\
Total & &
\end{tabular}

\section{Sociodemographic characteristics}

Figure 1 shows the Geographical distribution of the people interviewed in the localities of the commune of Kenscoff served by the Fermathe hospital. 


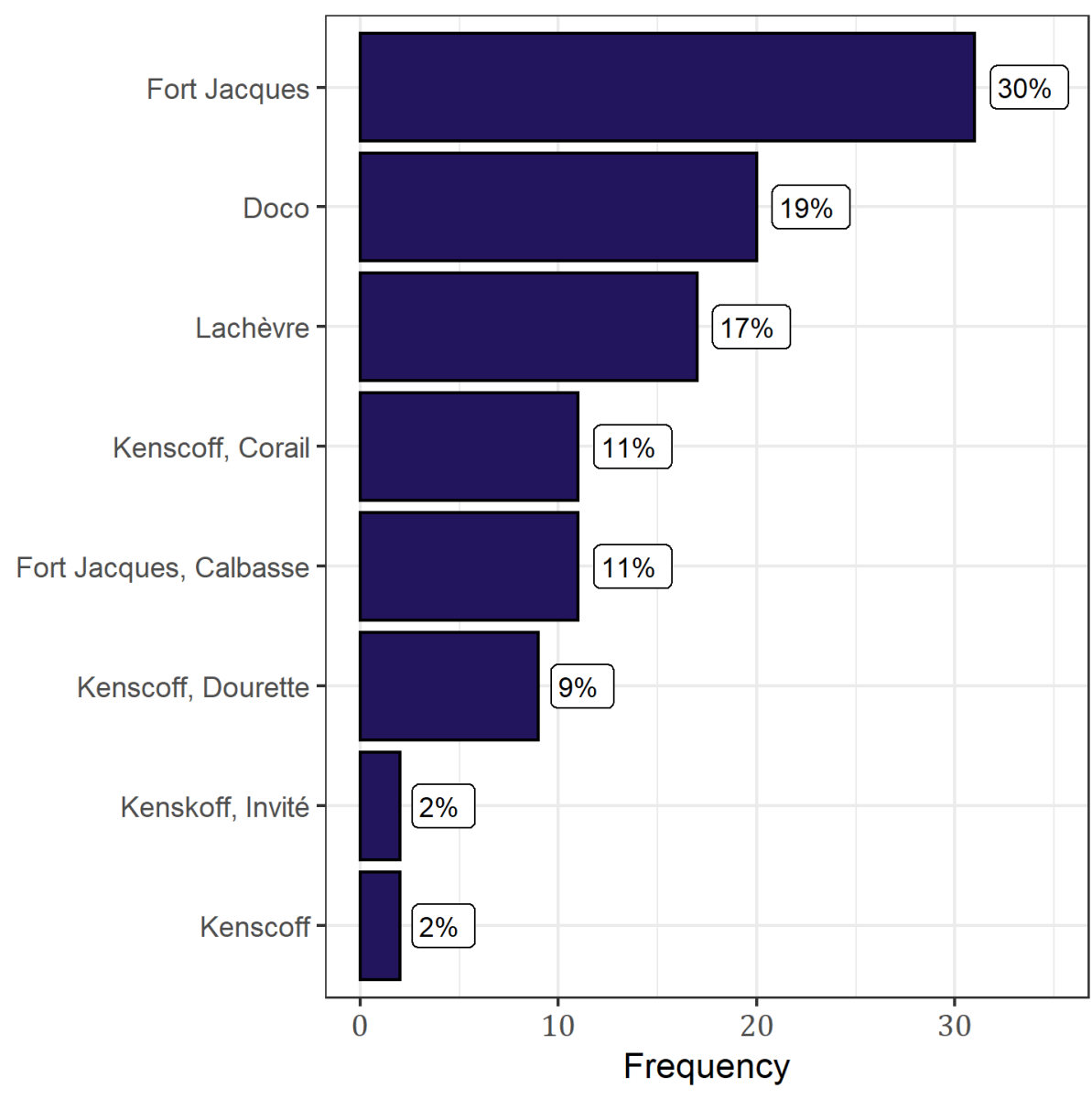

Data source: Parasitosis prevalence survey / Fermathe, Haiti / Jan. 12-13, 2021

Figure 1: Distribution of interviewees by geographic area

Sociodemographic and hygienic characteristics of people who have been the subject of voluntary observations or interviews

The hygienic parameters considered mainly refer to drinking water, water for domestic use (handwashing, food), hand washing, and instead of defecation. (Fig. 2, 3, 4).

The distribution of the sample according to the quality of drinking water and the prevalence of parasitosis is presented in Figure 2.

Note that among the various services mentioned in this study, which offer drinking water to the population, the water supplied by Culligan is the only product whose conservation packaging and hygiene measures are respected. 


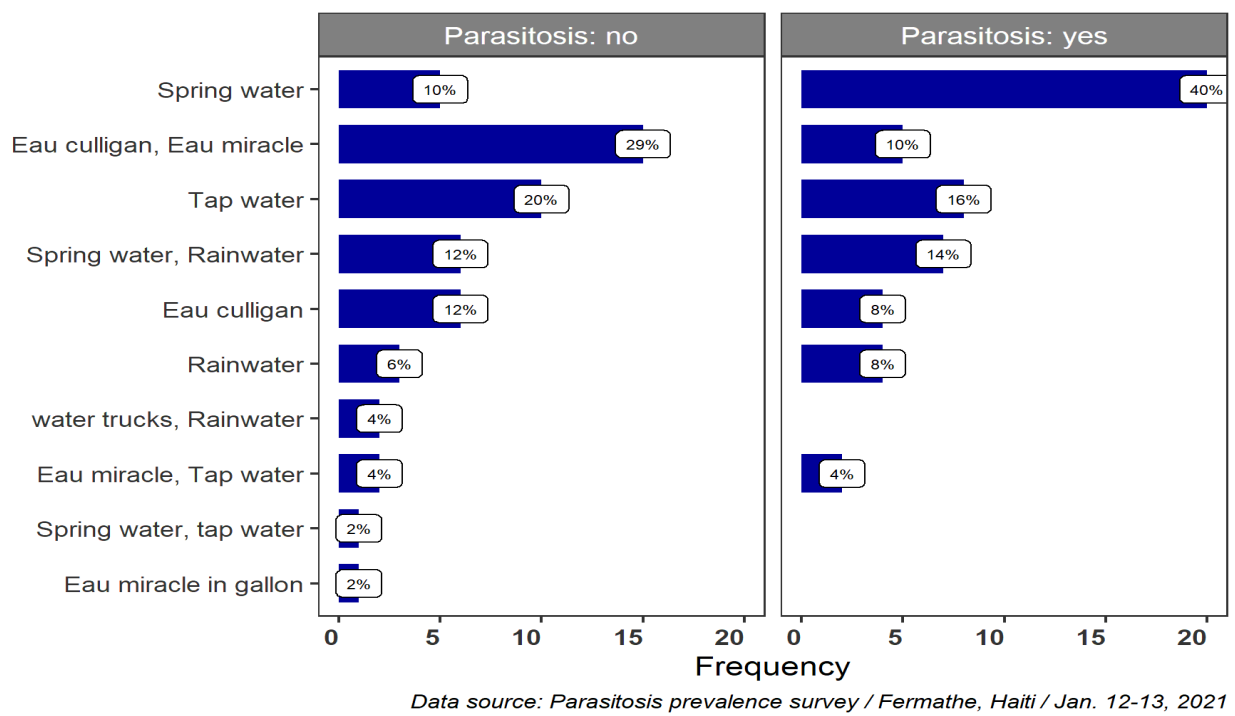

Figure 2: Distribution of the sample according to the quality of drinking water and the prevalence of parasitosis

Figure 3 shows the distribution of the sample according to the place of defecation and the prevalence of parasitosis.

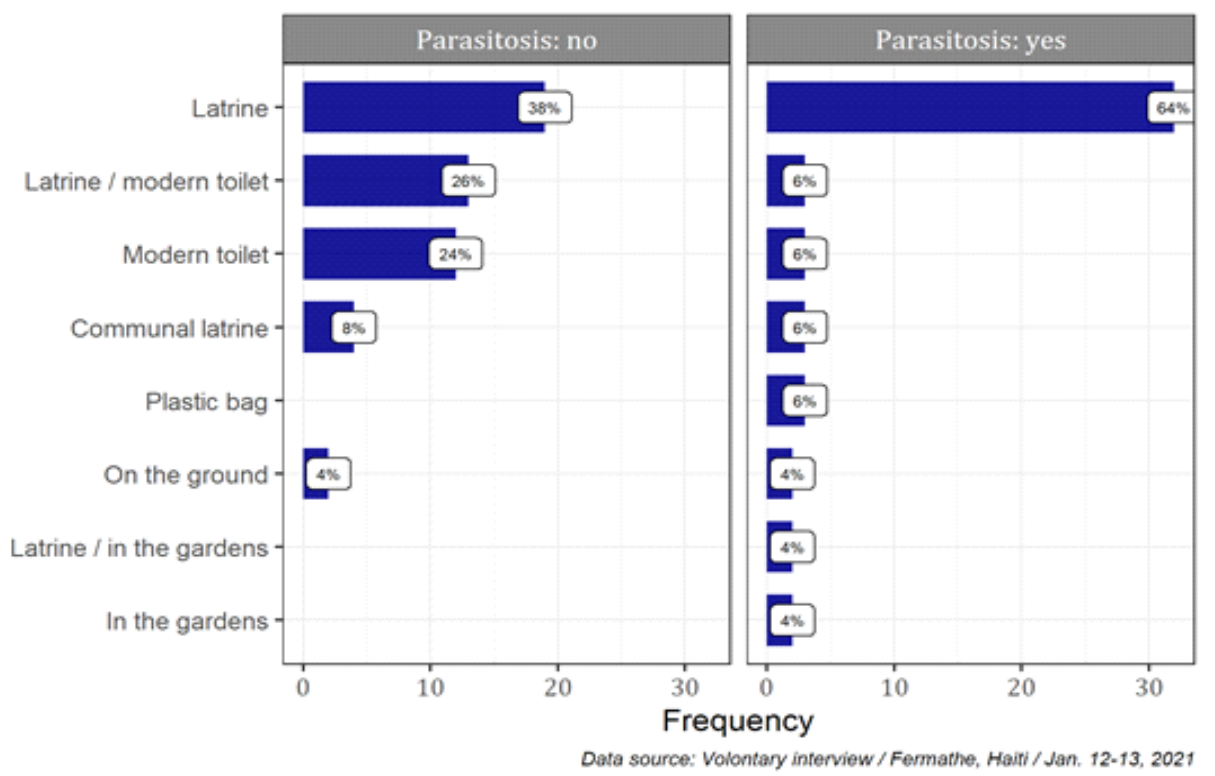

Figure 3: Distribution of the sample according to the place of defecation and the prevalence of parasitosis

Note that concerning personal hygiene, there is more than one answer per person. For hand washing on the one hand, and washing fruits, salads, and vegetables, on the other hand, before consumption, $88.5 \%$ and $92.9 \%$ 
respectively answered positively to these questions. $50.5 \%$ of the inhabitants of the area replied that they were familiar with people who suffer from parasitosis with the following clinical manifestations: abdominal pain, diarrhea, anal pruritus in children, polydypsia, nocturnal teeth grinding, and others. On the other hand, $61.4 \%$ of them report having been treated with traditional medicines at home without having attended a hospital center.

Figure 4 summarizes the analysis of the prevalence of parasitosis from handwashing.

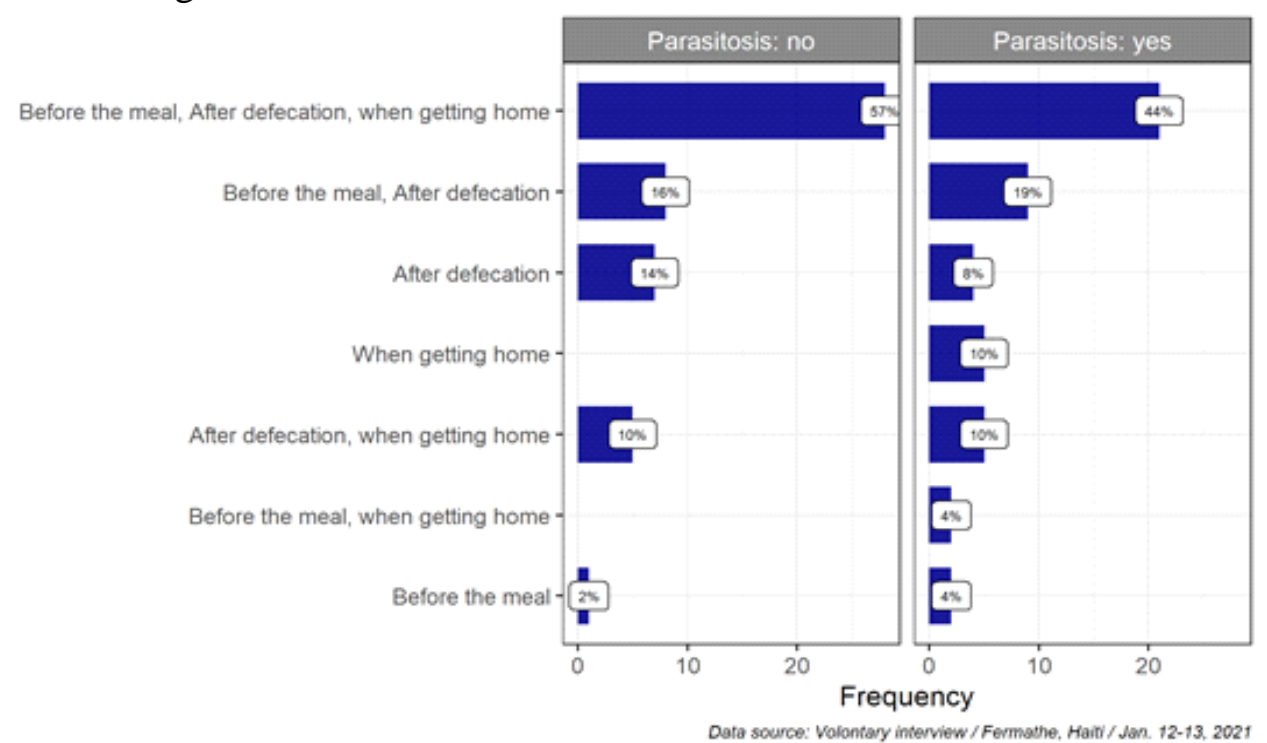

Figure 4: Prevalence of parasitosis and the habit of washing hands

The schematic representation of the CART model of the relationship between the site of defecation and the possibility of parasitosis is shown in Figure 5. 


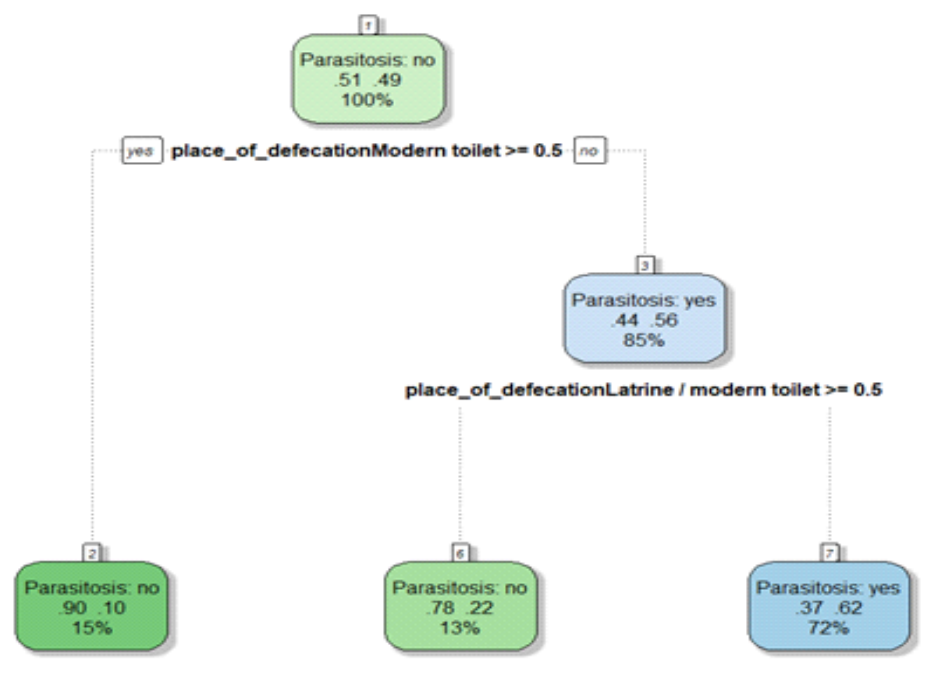

Rattle 2021-fevr-27 22:24:06 Lucainson Raymond

Figure 5: Schematic representation of the CART model of the relationship between the site of defecation and the possibility of parasitosis

In this study, the frequencies of protozoa and helminths are higher than those described in the study carried out in Turbaco [Villafañe-Ferrer, 2016]. In both cases, the most frequent parasite is Endolimax nana, i.e. 26.5\%) in Turbaco, and $39.13 \%$ (Fermathe, Haiti).

Blastocystis hominis is one of the protozoa isolated with the highest frequency in patients at Fermathe Hospital (14\%), which does not differ from the study carried out at Turbaco, and from another study conducted for determining the prevalence of bacteria and intestinal parasites in food handlers working with Cuban health workers in Haiti (Llanes, 2011). This protozoan is transmitted through contaminated water and food, and its frequency is linked to defecation on the ground, poor environmental sanitation, poor hygiene practices, and overcrowding. A study carried out in Côte d'Ivoire on the effects of hygiene and defecation behaviors on the presence of helminths and intestinal protozoan infections in Taabo revealed that age, sex, socioeconomic status, hygiene, and defecation behavior are determinants for the proliferation of helminths and intestinal protozoan infections [Schmidlin et al, 2013]. Indeed, it was revealed that in this region, only one in five households had access to latrines and that, as a result, open defecation was common. These conditions were met in certain areas of the municipality of Kenscoff, which probably influenced the high percentage of parasites and the results of the CART model. However, basically, $51 \%$ of the individuals used by the algorithm have intestinal parasites; the remaining $49 \%$, no. At the first 
partitioning, if the place of household defecation is "modern toilet", the probability that there is no individual suffering from an intestinal parasitosis is $90 \%$ against $9 \%$ for there to be. Note that $15 \%$ of the total sample is used at this node. On the other hand, if the household does not have a modern toilet, the probability that no individuals are suffering from an intestinal parasitosis drops to $56 \%$ compared to $44 \%$ who do not. Note that $85 \%$ of the sample is used at this level. Descending the tree, we see that if the household does not have a modern toilet (as the only place for defecation), but has both at the same time (latrine and modern toilet), the probability that there is no of an individual suffering from an intestinal parasitosis is $78 \%$ against $22 \%$ for it. Whereas, if the household has neither a modern toilet (as the only place for defecation) nor a "modern toilet and toilet", the probability that there are individuals without intestinal parasites is $37 \%$ against a $62 \%$ chance it will. Note that the proportion of the sample used is $72 \%$.

The female sex was more affected by the presence of cysts or vegetative forms of protozoa and/or roundworm eggs in the stool, i.e. 57\% of patients with an average age of 33 years, although several studies demonstrate the relationship between intestinal parasites and anemia in pregnant women, it can be noted in this study that the majority of women are women of childbearing age. The hygiene practices of the inhabitants of the area are similar to those observed in other studies carried out in Alabama by Mckenna in 2017 and other countries of Latin America. [McKenna et al, 2017].

The population of this commune makes great use of medicinal plants or natural potions for the treatment of worms such as boulou (name given to an antiparasitic plant), a fusion of herbal tea from the roots of plants with an antiparasitic effect, but this practice should be supported. by in-depth studies comparable to the study carried out on the anthelmintic properties of traditional African and Caribbean medicinal plants: Identification of extracts with potent activity against Ascaris suum in vitro. [Williams et al, 2016].

\section{Conclusion}

The results of this study indicate that intestinal parasitic infections or infestations are important causes of gastrointestinal disturbances and are present in the study area. These results at least confirm that these infections remain a major public health problem in Haiti. Thus, effective control programs to reduce the prevalence and incidence of intestinal parasitic infections should be considered in public health policies.

Author Contributions: Conceptualization of the study - Daphnée Michel et Max François Millien. Writing of the original study protocol Daphnée Michel. Review of the protocol - Max François Millien and Evens Emmanuel. Preparation of the data collection tool - Daphnée Michel. 
Validation of the data collection tool - Max François Millien and Evens Emmanuel. The data collection, the processing of data and their analysis Daphnée Michel, Ammcise Apply, Daphenide St Louis and Lucainson Raymond. Writing of the first draft of the paper - Daphnée Michel. Review, editing and revised version - Max François Millien, Ketty Balthazard-Accou and Evens Emmanuel. All authors have read and agreed to the published version of the manuscript.

Acknowledgments: The authors are thankful to the "One Health" University Space of Quisqueya University, FOKAL-Open Society Foundation Haiti, the Agence Universitaire de la Francophonie (AUF), the Representation of the Institute of Research for Development (IRD) in Mexico, Cuba, and Haiti, and the AOG (Association Communautaire Paysanne des Originaires de Grande Plaine), for their support in carrying out this study. We also thank the staff of the Jean Mossanto Health Center in Jalousie for contributing to the survey.

Conflicts of Interest: The authors declare no conflict of interest. The funders had no role in the design of this study; in the collection, analyses, or interpretation of data; in the writing of the manuscript, or in the decision to publish the results.

\section{References:}

1. Anderson, D. M., Coats, D. W., \& Tyler, M. A. (1985). Encystment of the Dinoflagellate Gyrodinium Uncatenum: Temperature and nutrient effects 1. Journal of Phycology, 21(2), 200-206. https://doi.org/10.1111/j.0022-3646.1985.00200.x

2. Balthazard-Accou, K., Emmanuel, E., Agnamey, P., \& Raccurt, C. (2020). Pollution of water resources and environmental impacts in urban areas of developing countries: case of the City of Les Cayes (Haiti). Environ Health Manag Prev Pract.

3. Balthazard-Accou, K., Emmanuel, E., Agnamey, P., Brasseur, P., Lilite, O., Totet, A., \& Raccurt, C. P. (2009). Presence of Cryptosporidium oocysts and Giardia cysts in the surface water and groundwater in the City of Cayes, Haití. Aqua-Lac, 1(1), 63-71. https://doi.org/10.29104/phi-aqualac/2009-v1-1-06

4. Bourée, P. (2015). Les parasitoses intestinales sont encore fréquentes. Med Santé Trop. 2015 Apr-Jun; 25 (2):130. DOI : 10.1684/mst.2015.0459

5. Brasseur, P., Agnamey, P., Emmanuel, E., Pape, J. W., Vaillant, M., \& Raccurt, C. P. (2011). Cryptosporidium contamination of surface and water supplies in Haiti. Archives of environmental \& occupational health, 66(1), 12-17. https://doi.org/10.1080/19338244.2010.506492 
6. Brownlee, J. (2016). Bagging and Random Forest Ensemble Algorithms for Machine Learning, Machine Learning Algorithms website.

7. Bruce, P., Bruce, A., \& Gedeck, P. (2020). Practical Statistics for Data Scientists: 50+ Essential Concepts Using R and Python. O'Reilly Media.

8. Cabral J. P. (2010). Water microbiology. Bacterial pathogens and water. International journal of environmental research and public health, 7(10), 3657-3703. https://doi.org/10.3390/ijerph7103657

9. Castro, GA. (1996). Helminths: Structure, Classification, Growth, and Development. In: Medical Microbiology. 4th ed. University of Texas Medical Branch at Galveston, Galveston (TX). PMID: 21413320

10. Cavalier-Smith, T. (2017). Origin of animal multicellularity: precursors, causes, consequences-the choanoflagellate/sponge transition, neurogenesis and the Cambrian explosion. Philosophical transactions of the Royal Society of London. Series B, Biological sciences, 372(1713), 20150476.

https://doi.org/10.1098/rstb.2015.0476

11. Champetier de Ribes, G., Fline, M., Désormeaux, A.M., Eyma, E., Matagut, P., Champagne, C., Pierre, J., Pape, J.W., Raccurt, C.P (2005). Prévalence des helminthoses intestinales en milieu scolaire en Haït : résultats de la première enquète nationale réalisée en 2002. Bull Soc Pathol Exot, 98(2), 127-132.

12. Cole, G. T. (1996). Basic biology of fungi. Medical Microbiology. 4th edition. PMID: 21413296

13. Damiani, C., Balthazard-Accou, K., Clervil, E., Diallo, A., Da Costa, C., Emmanuel, E., Totet, A., \&Agnamey, P. (2013). Cryptosporidiosis in Haiti: surprisingly low level of species diversity revealed by molecular characterization of Cryptosporidium oocysts from surface water and groundwater. Parasite (Paris, France), 20, 45. https://doi.org/10.1051/parasite/2013045

14. Ezeamama, A. E., Friedman, J. F., Acousta, L., Bellinger, D. C., Langdon, G. C., Manalo, D. L... and McGarvey, S. T. (2005) Helminthes infection and cognitive impairment among Filipino children. American Journal of Tropical Medicine and Hygiene. 72 (5): 540-548.

15. Gelting, R., Bliss, K., Patrick, M., Lockhart, G., \& Handzel, T. (2013). Water, sanitation and hygiene in Haiti: past, present, and future. The American journal of tropical medicine and hygiene, 89(4), 665-670. https://doi.org/10.4269/ajtmh.13-0217 
16. Hechenbleikner, E. M., \& McQuade, J. A. (2015). Parasitic colitis. Clinics in colon and rectal surgery, 28(2), 79-86. https://doi.org/10.1055/s-0035-1547335

17. Hesse AA, Nouri A, Hassan HS, Hashish AA. Parasitic infestations requiring surgical interventions. Sem in Pediatr Surg. 2012 May;21(2):142-50. doi: 10.1053/j.sempedsurg.2012.01.009. PMID: 22475120.

18. Incani RN, Ferrer E, Hoek D, Ramak R, Roelfsema J, Mughini-Gras L, Kortbeek T, Pinelli E. Diagnosis of intestinal parasites in a rural community of Venezuela: Advantages and disadvantages of using microscopy or RT-PCR. Acta Trop. 2017 Mar;167:64-70. doi: 10.1016/j.actatropica.2016.12.014. Epub 2016 Dec 19. PMID: 28007484

19. James, Gareth, Daniela Witten, Trevor Hastie, and Robert Tibshirani. 2014. An Introduction to Statistical Learning: With Applications in R. Springer Publishing Company, Incorporated.

20. Jarquin C, Arnold BF, Muñoz F, Lopez B, Cuéllar VM, Thornton A, Patel J, Reyes L, Roy SL, Bryan JP, McCracken JP, Colford JM. Population Density, Poor Sanitation, and Enteric Infections in Nueva Santa Rosa, Guatemala. Am J Trop Med Hyg. 2016 Apr;94(4):912919. doi: 10.4269/ajtmh.15-0555. Epub 2016 Feb 8. PMID: 26856919; PMCID: PMC4824239.

21. Juárez, M.M., Rajal, V.B. (2013). Parasitosis intestinales en Argentina: principales agentes causales encontrados en la población y en el ambiente. Rev Argent Microbiol. 45(3):191-204. Spanish. doi: 10.1016/s0325-7541(13)70024-5. PMID: 24165144

22. Kiani H, Haghighi A, Rostami A, Azargashb E, Tabaei SJ, Solgi A, Zebardast N. Prevalence, Risk Factors and Symptoms Associated to Intestinal Parasite Infections among patients with gastrointestinal disorders in Nahavand, Western Iran. Rev Inst Med Trop Sao Paulo. 2016;58:42. doi: 10.1590/S1678-9946201658042. Epub 2016 May 24. PMID: 27253744; PMCID: PMC4879999.

23. King IL, Li Y. Host-Parasite Interactions Promote Disease Tolerance to Intestinal Helminth Infection. Front Immunol. 2018 Sep 20;9:2128. doi: 10.3389/fimmu.2018.02128. PMID: 30298071; PMCID: PMC6160735.

24. Llanes R, Somarriba L, Velázquez B, Núñez FA, Villafranca CM. Low prevalence of Vibrio cholerae $\mathrm{O} 1$ versus moderate prevalence of intestinal parasites in food-handlers working with health care personnel in Haiti. Pathog Glob Health. 2016;110(1):30-2. doi: 10.1080/20477724.2016.1141471. Epub 2016 Mar 4. PMID: 27077312; PMCID: PMC4870026. 
25. McKenna ML, McAtee S, Bryan PE, Jeun R, Ward T, Kraus J, Bottazzi ME, Hotez PJ, Flowers CC, Mejia R. Human Intestinal Parasite Burden and Poor Sanitation in Rural Alabama. Am J Trop Med Hyg. 2017 Nov;97(5):1623-1628. doi: 10.4269/ajtmh.17-0396. Epub 2017 Oct 10. Erratum in: Am J Trop Med Hyg. 2018 Mar;98(3):936. PMID: 29016326; PMCID: PMC5817782.

26. Okolo, S. N, and John, C. (2006). Nutritional status and intestinal parasitic infestation among rural Fulani children in Vom, Plateau State. Nigerian Journal of Paediatrics 33: 47-55.

27. Oluboyo, B. O., Enweani, I. B., Ekejindu, I. M., \& Oluboyo, A. O. (2014). Prevalence of some intestinal parasitic infections in relation to body mass index of children resident in Orphanages in Anambra state, Nigeria. European Scientific Journal, 10(36).

28. Pape J.W., Levine E., Beaulieu M.E., Marshall F., Verdier R. \& Johnson W.D. (1987) Cryptosporidiosis In Haitian Children. The American Journal Of Tropical Medicine And Hygiene, 36, 333-337. https://doi.org/10.4269/ajtmh.1987.36.333

29. Pitt, T. L., \& Barer, M. R. (2012). Classification, identification and typing of micro-organisms. Medical Microbiology, 24-38. https://doi.org/10.1016/B978-0-7020-4089-4.00018-4

30. Raccurt C.P., Brasseur P., Verdier R.I., Eyma E., Li X., Pannier Stockman C., Agnamey P., Guyot K., Liautaud B., Dei-Cas E., Nevez G., Pape J.W. (2006). Cryptosporidiose humaine et espèces en cause en Haïti. Trop Med Int Health, 11 (6):929934 https://doi.org/10.1111/j.1365-3156.2006.01631.x

31. Ringo, D. L. (1967). Flagellar motion and fine structure of the flagellar apparatus in Chlamydomonas. The Journal of cell biology, 33(3), 543571. https://doi.org/10.1083/jcb.33.3.543

32. Savioli, L., Smith, H., \& Thompson, A. (2006). Giardia and Cryptosporidium join the 'neglected diseases initiative'. Trends in parasitology, 22(5), 203-208. https://doi.org/10.1016/j.pt.2006.02.015

33. Schmidlin, T., Hürlimann, E., Silué, K.D., Yapi, R.B., Houngbedji, C., Kouadio, B.A., Acka-Douabélé, C.A., Kouassi, D., Ouattara, M., Zouzou, F., Bonfoh, B., N'Goran, E.K., Utzinger, J., Raso, G. (2013). Effects of hygiene and defecation behavior on helminths and intestinal protozoa infections in Taabo, Côte d'Ivoire. PLoS One. 8(6):e65722. https://doi.org/10.1371/journal.pone.0065722

34. Tamramat, I. R. and Olowu, A. O. (2008). Study on prevalence and nutritional effect of helminthic infection in pre-school rural children in Nigeria. Nigerian Journal of Medical Practice 54:16-20.

35. Tungtrongchitr, A., Manatsathit, S., Kositchaiwat, C., Ongrotchanakun, J., Munkong, N., Chinabutr, P., Leelakusolvong, S., 
Chaicumpa, W. (2004). Blastocystishominis infection in irritable bowel syndrome patients. Southeast Asian J Trop Med Public Health. 35(3):705-10. PMID: 15689092.

36. Villafañe-Ferrer, L.M., Pinilla-Pérez, M. (2016). Intestinal parasites in children and soil from Turbaco, Colombia and associated risk factors. Rev Salud Publica (Bogota). 18(1):117-128. http://dx.doi.org/10.15446/rsap.v18n1.42471

37. Williams, A. R., Soelberg, J., \& Jäger, A. K. (2016). Anthelmintic properties of traditional African and Caribbean medicinal plants: identification of extracts with potent activity against Ascaris suum in vitro. Parasite, 23. 10.1051/parasite/2016024

38. WHO/UNICEF, (2012). Progress on Drinking Water and Sanitation: 2012. WHO/UNICEF Joint Monitoring Programme (JMP) for Water Supply and Sanitation.

http://www.wssinfo.org/fileadmin/user_upload/resources/JMP-report2012-en.pdf

39. Zhang Z. (2016). Decision tree modeling using R. Annals of translational medicine, 4(15), 275.

https://doi.org/10.21037/atm.2016.05.14 